\title{
On the Origin of the Early Christian Artistic Tradition in Byzantine Chersonesos
}

\author{
By Anna N. Litovchenko* \\ Michail V. Fomin ${ }^{\dagger}$ \\ Aleksey G. Chekal
}

\begin{abstract}
Despite the considerable number of well known Byzantine centres, ChersonesosKherson is one of the few where systematic archaeological research has been conducted. More than 150 years of excavations at the site have resulted in the discovery of a significant number of artifacts. Among them a prominent place is taken by Christian churches. The elements of ornament, sculpture, monumental painting and mosaics which have remained intact allow us to make some assumptions about the origin and development of the artistic tradition. The early Byzantine mosaics are a subject of special interest. The main goal of this article will be to represent and analyse early Christian symbols of mosaic in Chersonesos-Kherson and in Syrian monuments. We would like to follow the direction of the origin of the artistic tradition in Chersonesos. The Byzantine mosaics of Chersonesos churches are those of peculiar interest, thus they always draw the researchers' attention. It would seem difficult to add something further to this but we have came across some materials dedicated to the early Christian mosaics of Syria. Study and comparison of the floor mosaics of the early Christian centres of Syria and Tauris in combination with other kinds of sources, has uncovered new material regarding the process of the establishment of the artistic tradition of early Byzantine Chersonesos. To sum up, one can state with certainty that close contacts between the eastern provinces of the Empire and Chersonesos-Kherson made a substantial impact on many aspects of the city's life, together with the spread of Christianity from the East. These artistic traditions were reflected in fresco paintings of the early Christian crypts of Chersonesos and in the mosaic floors of later churches. The existence of the artistic tradition was definitely reflected in the compositions of the floor mosaics of Chersonesos and Syrian churches. All this allows us to maintain that the system of floor mosaics paintings in Syria and Chersonesos has a common source. And, what is more, it would be logical to suggest that most of the artists belong to the Syrian artistic tradition.
\end{abstract}

Despite the fact that there are several well-known Byzantine centres, systematic archeological research has been conducted in only a few, particularly in Chersonesos-Kherson ${ }^{1}$. Excavations over a period of more than

\footnotetext{
*Master Student, Aristotle University of Thessaloniki, Greece.

${ }^{\dagger}$ Kharkiv Institut of Trade and Economics of Kyiv, National University of Trade and Economics, Ukraine.

*Kharkiv State Academy of Design and Arts, Ukraine.

${ }^{1}$ C. Foss, "Archeology and the "Twenty Cities" of Byzantine Asia" American Journal of Archeology, vol. 81. (1977): 469 - 486; Ch. Bouras, "City and Village: Urban and Architecture" Jahrbuch der Osterreichischen Byzantinistik 31, no. 2. (1981): 616 - 627; A.I.
} 
150 years resulted in the discovery of many artifacts, among which prominence of place is taken by Christian churches. The elements of ornament, sculptures, monumental paintings and mosaics that have been preserved intact make it possible to surmise about the origin and development of the artistic tradition. The Byzantine mosaics of Chersonesos churches in particular always draw the researchers' attention ${ }^{1}$. Their fullest description is given in the monograph by O.I. Dombrovski ${ }^{2}$. It would seem difficult to add something further to this but we have came across some materials dedicated to the early Christian mosaics of Syria. Studies in the field of the early Christian floor mosaics in Syria and Tauris, in combination with the other kinds of sources, has uncovered new material regarding the process of the establishment the artistic tradition of early Byzantine Chersonesos.

The text about the «Lives of Kherson's bishops» ${ }^{3}$ gives the grounds to assume that the first six bishops arrived in Chersonesos from Jerusalem. Thus, the this text the manner whereby Christianity came to the city and the influence of the Eastern tradition on the formation of the community.

The city had close economic ties with Asia Minor, which is proved by multiple archeological finds ${ }^{4}$. Continuous contacts, exchange of goods, and active visits to Chersonesos by the Eastern tradesmen naturally led to the development of cultural exchange.

A considerable number of both written and archeological sources allow us to acknowledge positively the spread of Christianity to the region of the Middle

Romanchuk, Issledovanija Hersonesa - Hersona. [Research Chersonesos - Kherson]. Part 2. (Ekaterinburg, 2007), 133 - 145.

${ }^{1}$ A. Uvarov, Hristianskaja simvolika. [Christian symbolism]. Moscow, 1908; A.L Bert'eDelagard "Drevnosti Juzhnoj Rossii. Raskopki Hersonesa" [Antiquities South Russia. Excavations Chersonesos] Materials for the archaeology of Russia. V. 12. (St. Petersburg, 1893): 56 -74; D.V. Aynalov, "Razvaliny hramov" [Temple ruins], Monuments of Christian Chersonesos, vol. 1, (1905): 137-143; M. Leiter, Iz materialov po izucheniju mozaichnyh polov Hersonesa Tavricheskogo. [From the materials for the study of the mosaic floors of Chersonesos]. (Kharkiv, 1928); S.F. Strzheletskiy, "Antichnye pamjatniki Hersonesa iz raskopok 1950 g."[Chersonesos ancient monuments from the excavations in 1950], Journal of Ancient History, no. 2. (1951): 136-139; A.L. Jacobson, "Rannesrednevekovyj Hersones: ocherki istorii material'noj kul'tury." [Early Medieval Hersonissos : Essays on the History of Material Culture], Materials and research on the archeology of the USSR, vol. 63 (MoscowLeningrad, 1959); A.L. Jacobson, "Srednevekovyj Hersones (XII-XIV vv.)" [Medieval Chersonesos (XII-XIV centuries)], Materials and research on the archeology of the USSR, vol. 17. (Moscow-Leningrad, 1950): 67-89 .

${ }^{2}$ O.I. Dombrovskij, Vizantijskie mozaiki Hersonesa Tavricheskogo [Byzantine mosaics Chersonesos.] (Poznan, 2004).

${ }^{3}$ Ju.M. Mogarichev, A.V. Sazanov, T.Je. Sargsjan, S.B. Sorochan, A.K. Shaposhnikov, "Zhitija episkopov Hersonskih v kontekste istorii Hersonesa Tavricheskogo" [Lives of the Bishops of Kherson in the context of the history of Chersonesos] Narteks. Byzantina Ukrainensis, vol.1. (Kharkiv: Antikva, 2012): 21-27.

${ }^{4}$ V.I. Kadeev, Hersones Tavricheskij. Byt i kul'tura (I - III vv. n. e.). [Chersonesos. Life and culture (I - III centuries. A.D.).] (Kharkiv, 1996), 57 - 59; V.I. Kadeev, S.B. Sorochan Ekonomicheskie svjazi antichnyh gorodov Severnogo Prichernomor'ja v I v. do n.e. $-V$ v. n.e. (po materialam Hersonesa). [Economic ties of ancient cities in the Northern Black Sea in the I. B.C. - V in. A.D. (based on the Chersonesos)]. (Kharkiv, 1989), 38 - 46. 
East during the first centuries A.D. ${ }^{1}$. The foundations of Christian artistic thinking were born in Syria. The late Hellenistic monuments of Palmira and Dura-Europos were called "Oriental forerunners of Byzantine art" ${ }^{\text {"2 }}$ by a number of scolars. J. Strzygowski made a well-known statement about the values of Parthian sacred art for East and stated: "What Hellas has contributed to the art of antiquity, Iran has contributed to the art of the new Christian world" 3 .

A range of themes and decorative elements in Hellenistic mosaics was formed and passed from one master to another. In the well-known work of Kurt Weitzmann ${ }^{4}$ consist a particular study of late Antiquity and early Christian miniatures. The technology of the mosaic work itself suggested availability of "portfolios" which contained replicas of themes and ornamental combinations. As it is noted in the murals of Dura-Europos, not only the compilations of outline drawings but also book illustrations served as a basis for monumental designs ${ }^{5}$. Syncretism of Hellenistic motifs, originating on the banks of the Euphrates, and the Eastern methods of space depiction are well distinguished in the sacred art of Palmira, Dura-Europos, and Edessa ${ }^{6}$ and later were transferred into other parts of the empire. This continuity was natural and logical and largely because the mosaics of Syria and the Black Sea region are closely related to each other.

A considerable number of the early Christian monumental pieces of art are preserved in the museums of mosaics in Marra and Apamea. Their collections are composed of mosaics that were collected in "dead cities" which are situated in the north of Syria between Aleppo and Hama (Apamea in 4th -5th centuries) ${ }^{7}$. Furthermore, analysis of themes, methods and prototypes of Chersonesos depictions testifies to a certain semantic and esthetic link of the

\footnotetext{
${ }^{1}$ V.V. Bolotov, Lekcii po istorii Drevnej Cerkvi. [Lectures on the History of the Ancient Church.] (Kharkiv, 2007), 253 - 258; A. Dvorkin Ocherki po istorii Vselenskoj Pravoslavnoj Cerkvi. [Essays on the history of the universal Church.] (Nizhny Novgorod, 2005), 122 - 124; M. E. Posnov Istorija hristianskoj Cerkvi (do razdelenija cerkvej - 1054). [History of the Christian Church (before the separation of church - 1054).] (Brussels, 1964) ,79 - 81; M. I. Rostovtzeff Dura - Europos and its Art. (Oxford, 1938), 127 - 130; G.M. Bongard-Levin, V.A. Gaibov, G.A. Koshelenko "Rasprostranenie hristijanstva na Vostoke (v svete issledovanija pamjatnikov Dura Evropos)" [Distribution christianity in the East (in the light of the study sites Dura Europos)], Journal of Ancient History,vol. 3 (2005): 58 - 72.

${ }^{2}$ J.H. Breasted, Oriental Forerunners of Byzantine Art Syria. (1922) (Chicago, 1924); M. I. Rostovtzeff Dura - Europos and its Art. (Oxford, 1938), 56.

${ }^{3}$ J. Strzygowski, Orient oder Rom: Beitrige zur Geschichte der Spitantiken und Frihchristlichen Kunst. (Leipzig, 1901), 18.

${ }^{4}$ K. Weizmann, Late Antique and Early Christian Book Illumination. (New-York, 1977)

${ }^{5} \mathrm{~K}$. Weitzmann, The Frescoes of the Dura Synagogue and Christian Art. (Washington: Dumbarton Oaks, 1990)

${ }^{6}$ A.G. Chekal, Epigrafika v sakral'nom i pogrebal'nom iskusstve Pal'miry i Dura-Evropos. [Epigraphy in the sacred and funerary art of Palmyra and Dura-Europos] Shodoznavchi studii. News of Harkovskoï derzhavnoï akademiï design i Mistetstvo 9, no. 1, ed. V.Y. Danilenko (Kharkiv, 2008): 56-68.
}

${ }^{7}$ A. Hadjar, The Church of St. Simeon the Stylite and other archaeological sites in the mountains of Simeon and Halaqa, (S.L, 1995), 1-6. 
artistic tradition. This subject matter has recently become of interest to scientists. Specifically A.E. Filippov examines in his works ${ }^{1}$ the influence of Dura-Europos monumental art on the wall-paintings of the early Christian crypts of Chersonesos.

Examination of the Chersonesos-Kherson monuments gives us grounds to state that ornamental motifs, such as depictions of grape vines, bunches of grapes, birds, animals and bowls predominate in the stylistic design of the mosaic floors of basilicas. The range of colors was represented by red, black, blue, yellow, dark cherry.

The symbol of a bird, which is very often a personification of a human soul $^{2}$, is wide-spread. Doves can be singled out as the symbol of the Holy Spirit. The peacock reflects the belief in immortality, which is based on the idea of the imperishability of its flesh. A peacock with an extended tail symbolizes the sky of $\operatorname{stars}^{3}$.

Amongst those depictions that occur most often, special attention should be paid to the "bowl" (in mosaics from the of the Countryside Cruciform Church situated on the necropol, Basilica No.15 also refered to as the «Basilica in Basilica», the 1935 Basilica) (see Figures 1-5). The cup symbolizes the Eucharist in Christian teaching "The Lord's flesh and blood". It is extremely significant that the depictions of the vessels, including those with the birds drinking from them, were the motifs for both Chersonesos and Syrian mosaics (see. Figures 1-8). They could symbolize the teaching of Christ and the immortality given by him (peacocks drinking from bowls).

\footnotetext{
${ }^{1}$ A.E. Filippov, "Rospisi rannehristianskih sklepov Hersonesa Tavricheskogo v kontekste hudozhestvennoj tradicii: sintez s arhitekturoj, simvolika, liturgicheskaja osnova." [Early Christian painting crypts Chersonesos in the context of artistic tradition: the synthesis of architecture, symbolism, liturgical foundation], Ocherki istorii hristianskogo Hersonesa. Essays on the History of the Christian Chersonesos, vol.1, issue. 1. (St Petersburg, 2009): 193-322.

${ }^{2}$ S.B. Sorochan, V.M. Zubar, L.V. Marchenko Zhizn' $i$ gibel' Hersonesa. [Life and death of Chersonesos.] (Kharkov, 2000), 614.

${ }^{3}$ A. Uvarov, Hristianskaja simvolika. [Christian symbolism]. (Moscow, 1908), 52.
} 
Figure 1. Chersonesos. From Early Mosaics of the 1935 Basilica. Kontharos

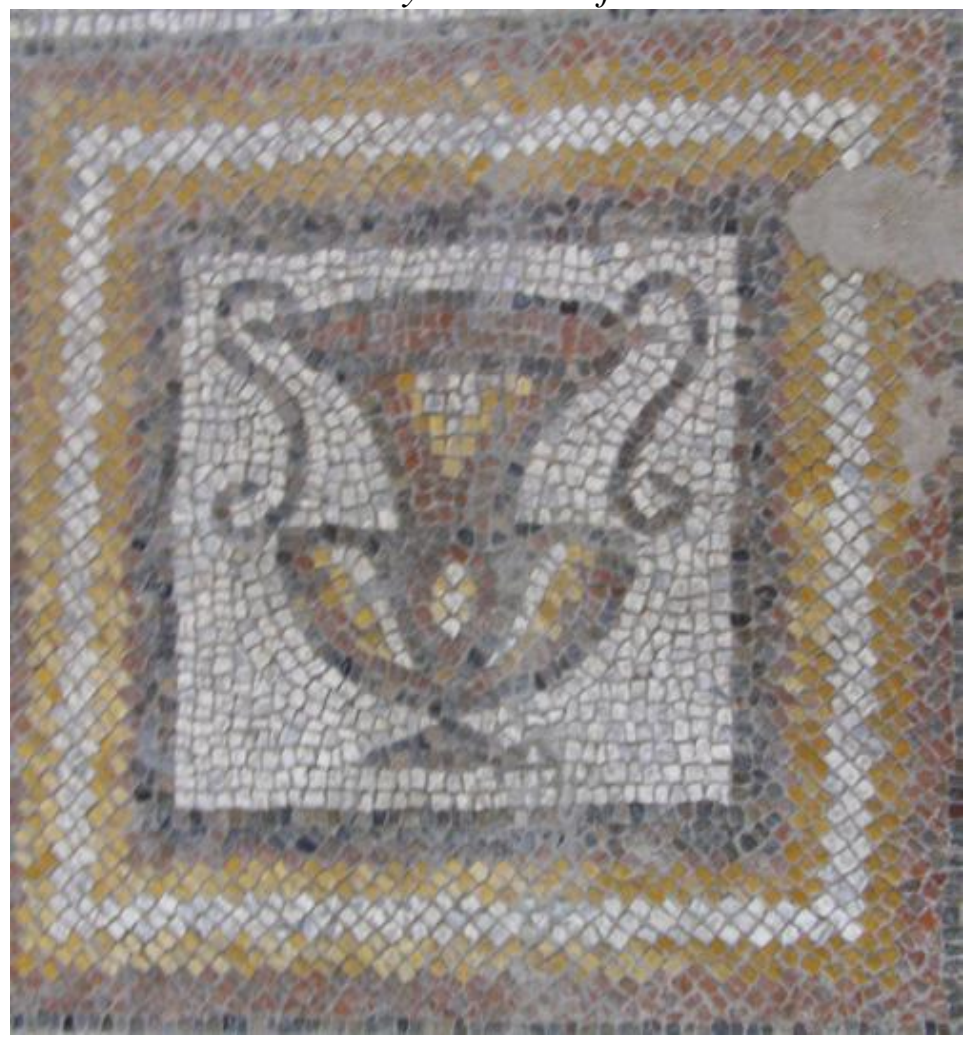

(Photo by A.M. Litovchenko)

Figure 2. Chersonesos. From Early Mosaics of the 1935 Basilica. A Bowl with a Growing Grape Vine

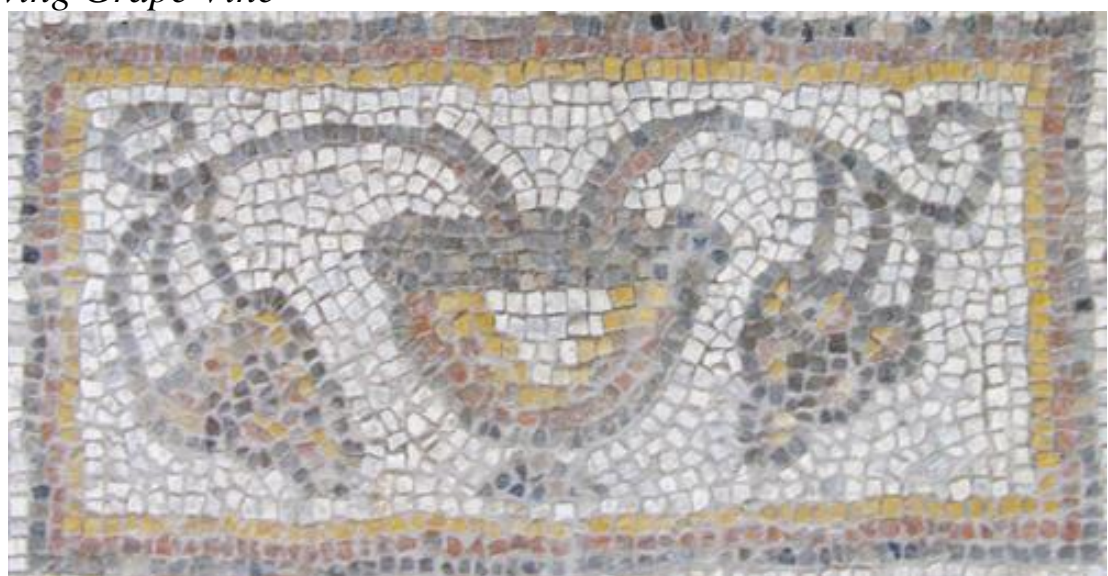

(Photo by A.M. Litovchenko) 
Figure 3. Chersonesos. From Mosaics of the Countryside Cruciform Church situated on Necropol. A Kilix in a Triangle

(Photo by M.V.Fomin)

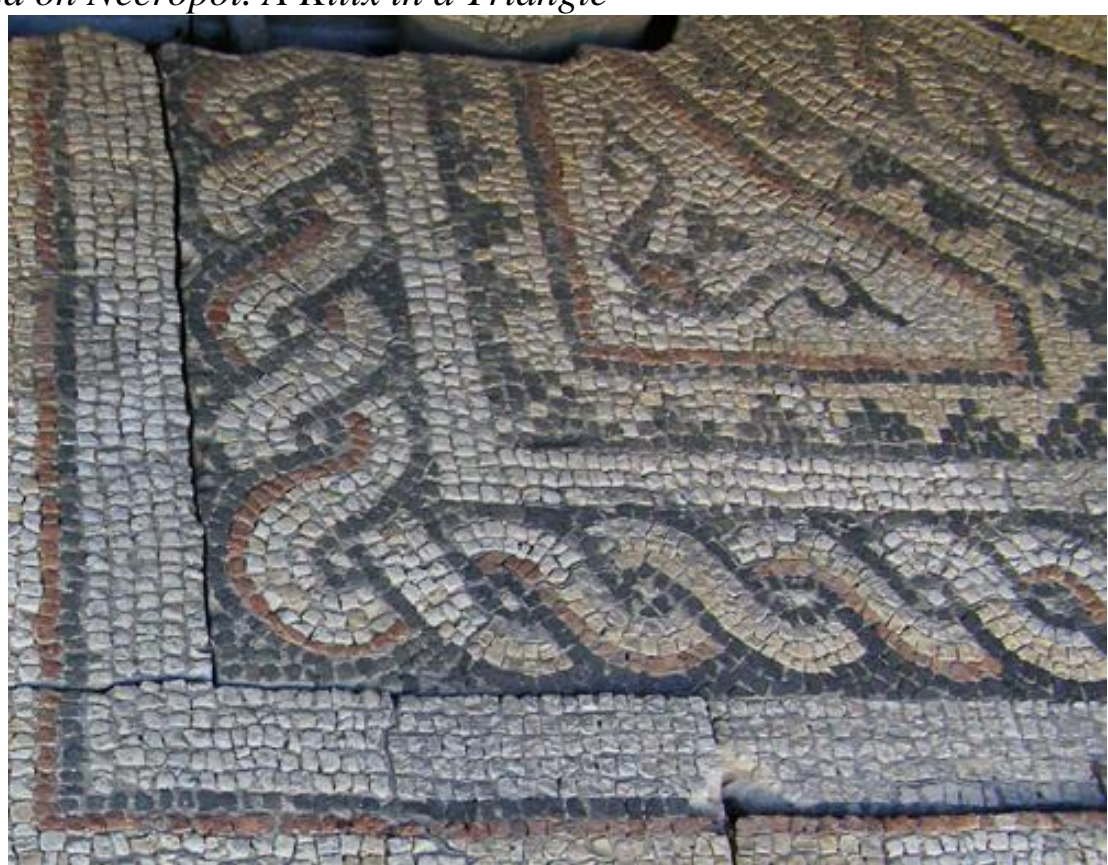

Figure 4. Chersonesos. From Mosaics of the Countryside Cruciform Churcht situated on Necropol. A Bowl with Birds and Grapes

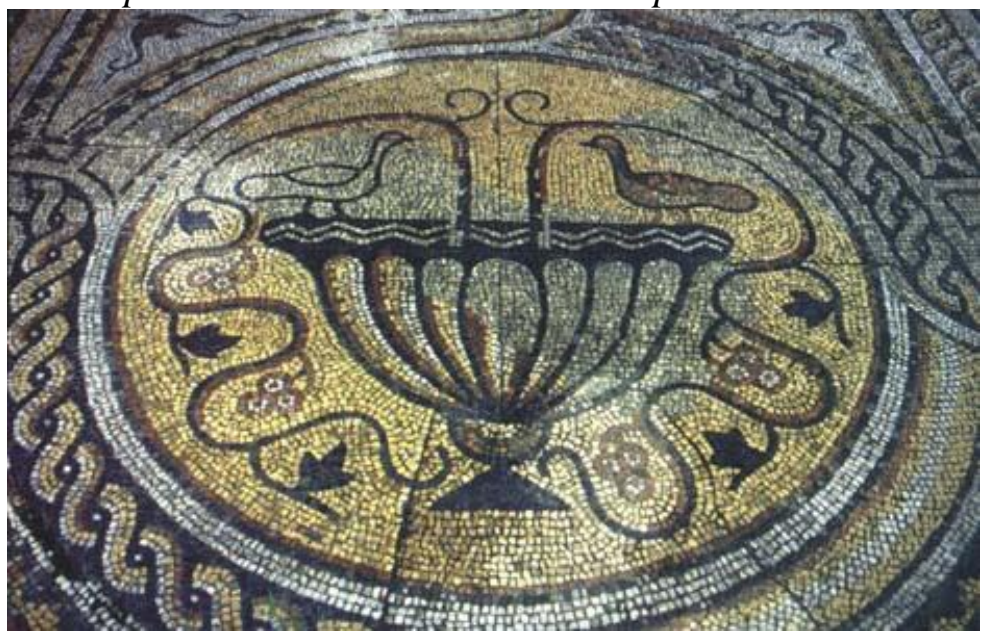

(O.I. Dombrovskij, Vizantijskie mozaiki Hersonesa Tavricheskogo [Byzantine mosaics Chersonesos.] (Poznan, 2004):72.) 
Figure 5. Chersonesos. From Mosaics of the Countryside Cruciform Churcht situated on Necropol. Central Image. Peacocks with a Vessel-kantharos

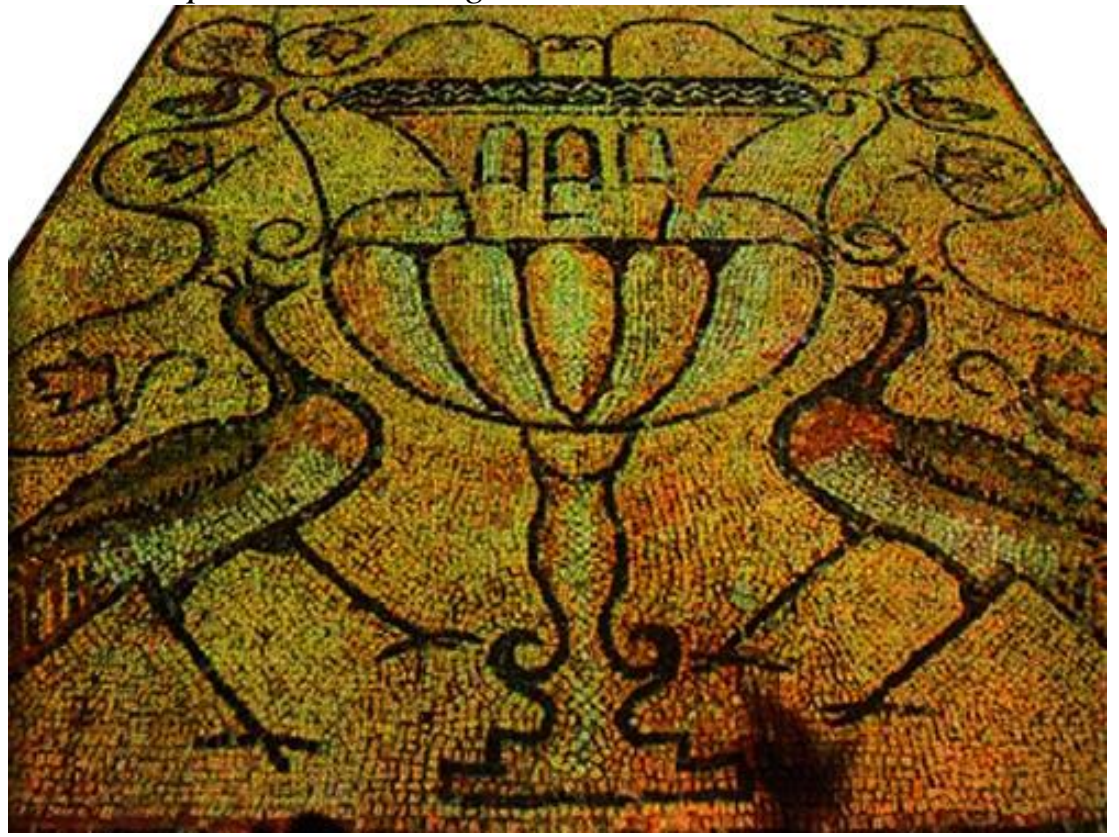

(Photo by M.V.Fomin)

Figure 6. Museum of Mosaic in Marra (Maraat an-numan). Peacocks with a Vessel-kantharos

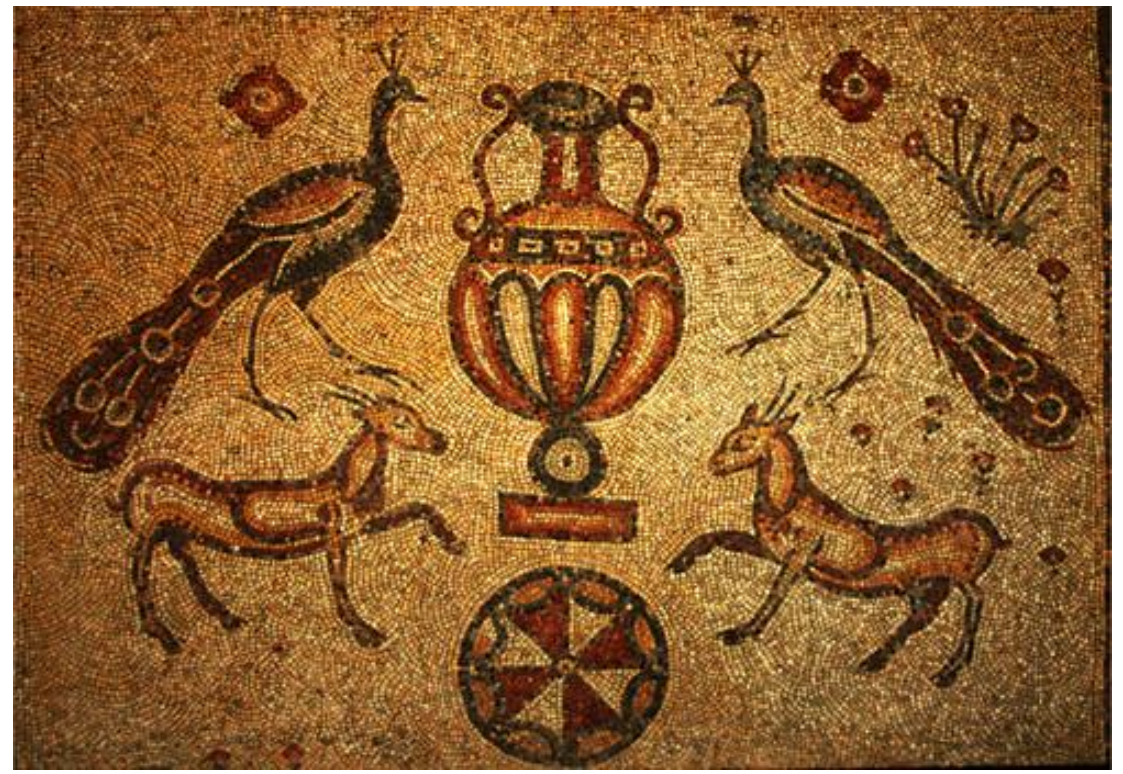

(Photo by O.G. Checal) 
Figure 7. Museum of Mosaic in Marra (Maraat an-numan). Peacocks with a Vessel

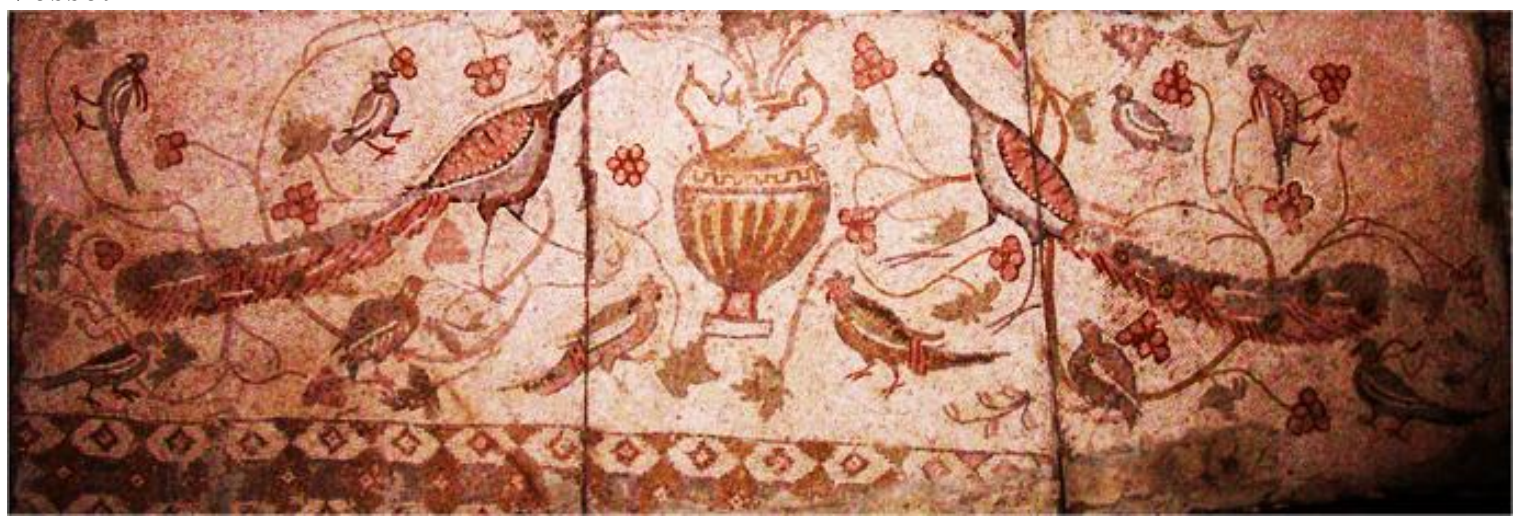

(Photo by O.G. Checal)

Figure 8. Chersonesos. Crypt "At the Site of N. I. Tur". Peacocks with a Garland

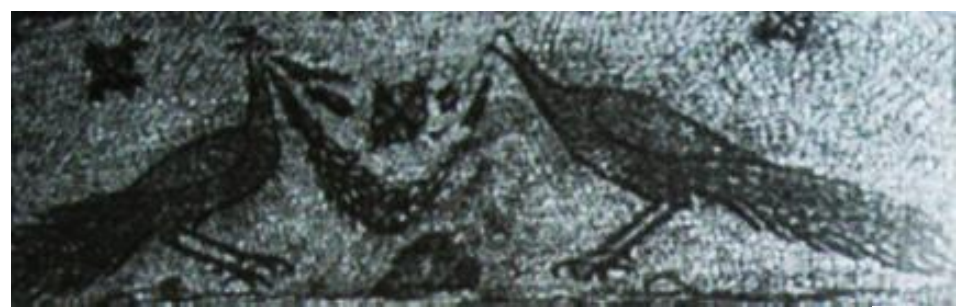

(M. I. Rostovtzeff, Antichnaya dekorativnaya zhivopis' na yuge Rossii [Ancient Decorative Painting in South Russia] (Saint Petersburg, 1914), 475.)

A significant place in early Christian symbolism is also presented by the vegetative images. Garlands of laurel leaves, flowers and trees symbolize the settings of the heavenly kingdom, paradise ${ }^{1}$. A wreath was the symbol of victory (laurel wreath), also victory over death, ${ }^{2}$ and it often symbolized martyrdom. Framing with grape leaves and bunches was also widespread (Basilica №15, Countryside Cruciform Church situated on the necropol, the 1935 Basilica, the 1932 Basilica, the Western Basilica (No.13)) - and its were the symbols of Christ's teaching ${ }^{3}$ (Christ the wine maker). There are also depictions of a diamond with rings on it (a symbol of eternity ${ }^{4}$ ) and the anchor (a symbol of hope ${ }^{5}$.

One of the images was the "cross". A resolution of the Third Council of Constantinople (680-681 A.D.), banned depictions of the cross on the floor. This aspect is testified to in the mosaics of the Uvarov Basilica (No.23), the

\footnotetext{
${ }^{1}$ A. Uvarov, Hristianskaja simvolika. [Christian symbolism]. (Moscow, 1908), 46.

${ }^{2}$ J. Xoll Slovar, sjuzhetov $i$ simvolov v iskusstve. [Dictionary of subjects and symbols in art.], trans. A. Maikapara (Moscow, 1996), 123.

${ }^{3}$ A. Uvarov, Hristianskaja simvolika. [Christian symbolism]. (Moscow, 1908), 34.

${ }^{4}$ J. Xoll Slovar' sjuzhetov i simvolov v iskusstve. [Dictionary of subjects and symbols in art.], trans. A. Maikapara (Moscow, 1996), 367.

${ }^{5}$ G. Biederman, Enciklopedija simvolov. [Encyclopedia symbols] trans. I.S. Sventsitskaya (Moscow, 1996), 435.
} 
from the Countryside Cruciform Church situated on the necropol and Basilica No. 15, where such depictions were presented. The themes mentioned above can be found both in the floor mosaics of the Chersonesos churches and in the fresco paintings of the painted crypts (see Figures 5, 8).

Mosaic carpets covered with a pattern were discovered in the Basilica No.15 and in the Uvarov Basilica (No.23) (see Figures 9, 10). They demonstrate patterns that are completely identical with the floor mosaics in Syrian museums (see Figures 11, 12). Similar links can be identified in the motifs of the framing of the mosaics Chersonesos (see Figures 3, 13) and Apamea (see Figure12).

As indicated above, a widespread theme was depiction of the Vessel. One of the variants is a Vessel-kilix in a triangle (Apamea (see Figures 14, 15), Chersonesos (see Figure 3)). Vessels with grapevine are known from the mosaics of the 1935 Basilica (see Figure 1), similar themes are presented in Syrian mosaics as well (see Figure 7).

Figure 9. Chersonesos. «The Carpet» in the Basilika No.15

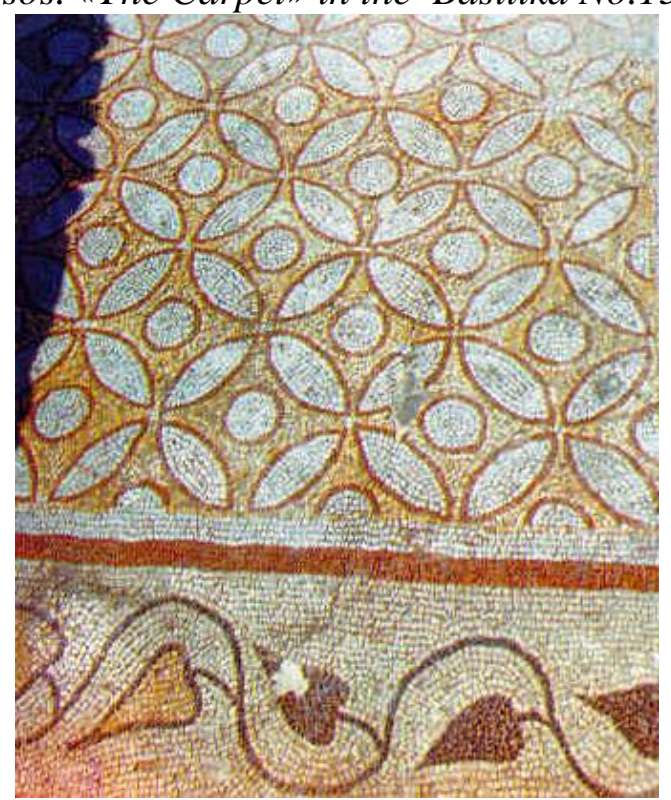

(O.I. Dombrovskij Vizantijskie mozaiki Hersonesa Tavricheskogo [Byzantine mosaics Chersonesos.] (Poznan, 2004), 53.) 
Vol. 1, No. $3 \quad$ Litovchenko et al.: On the Origin of the Early Christian Artistic...

Figure 10. Chersonesos. "The Carpet» from Nartex the Uvarov Basilica (No.23)

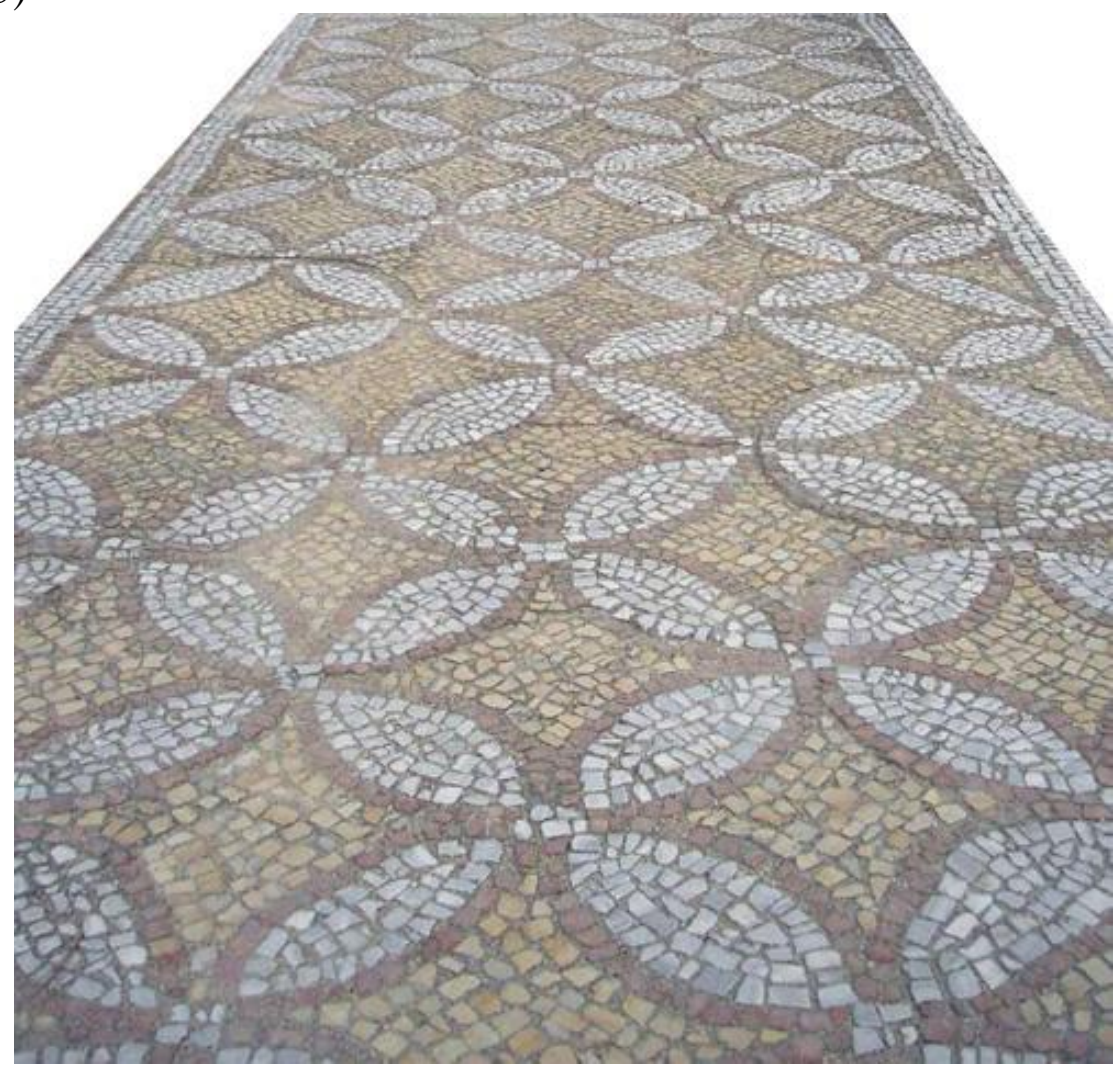

(Photo by A.M. Litovchenko)

Figure 11. Museum of Mosaic in Marra (Maraat an-numan). «A Carpet»

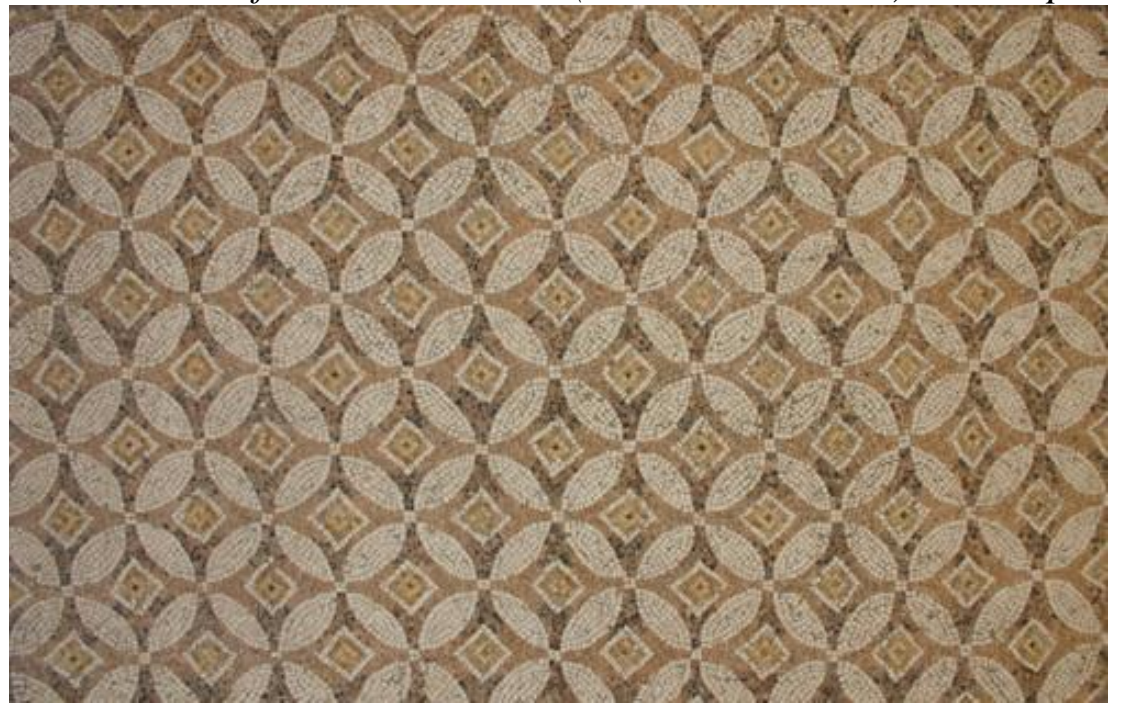

(Photo by O.G. Checal) 
Figure 12. Museum of Mosaic in Apamea (Hama). Patterns

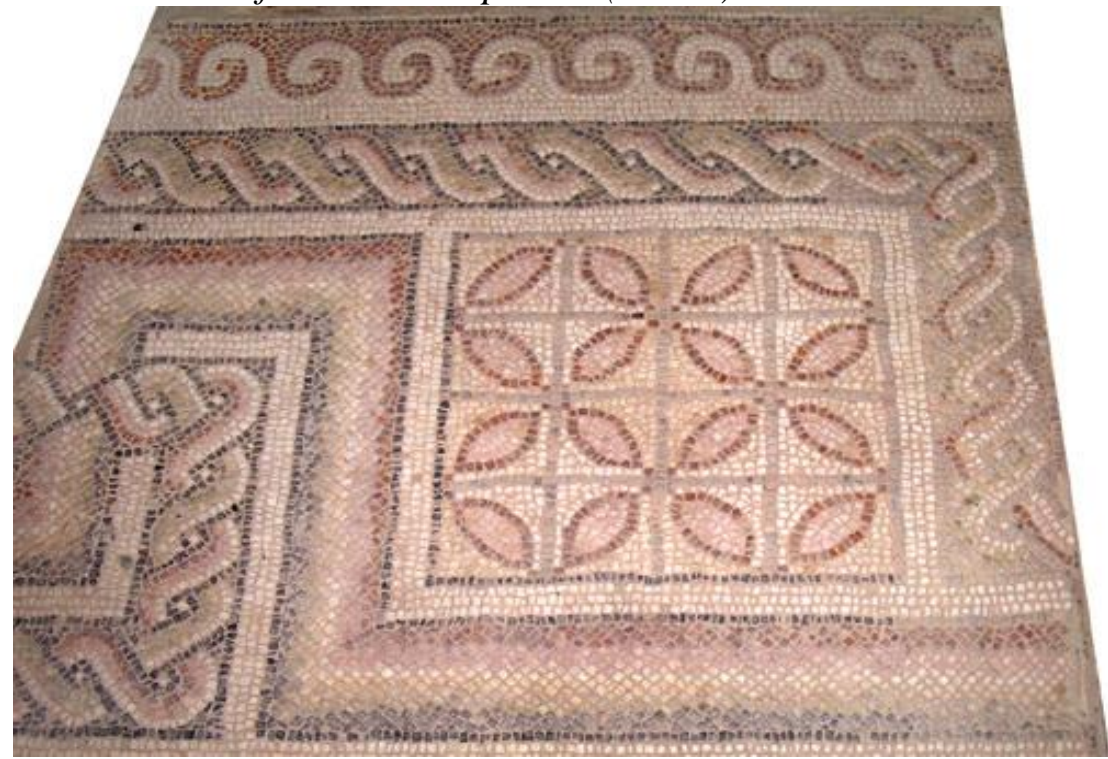

(Photo by O.G. Checal)

Figure 13. Chersonesos. From Mosaic of Cruciform of the Countryside Cruciform Churcht situated on Necropol. A Vine's Sallow

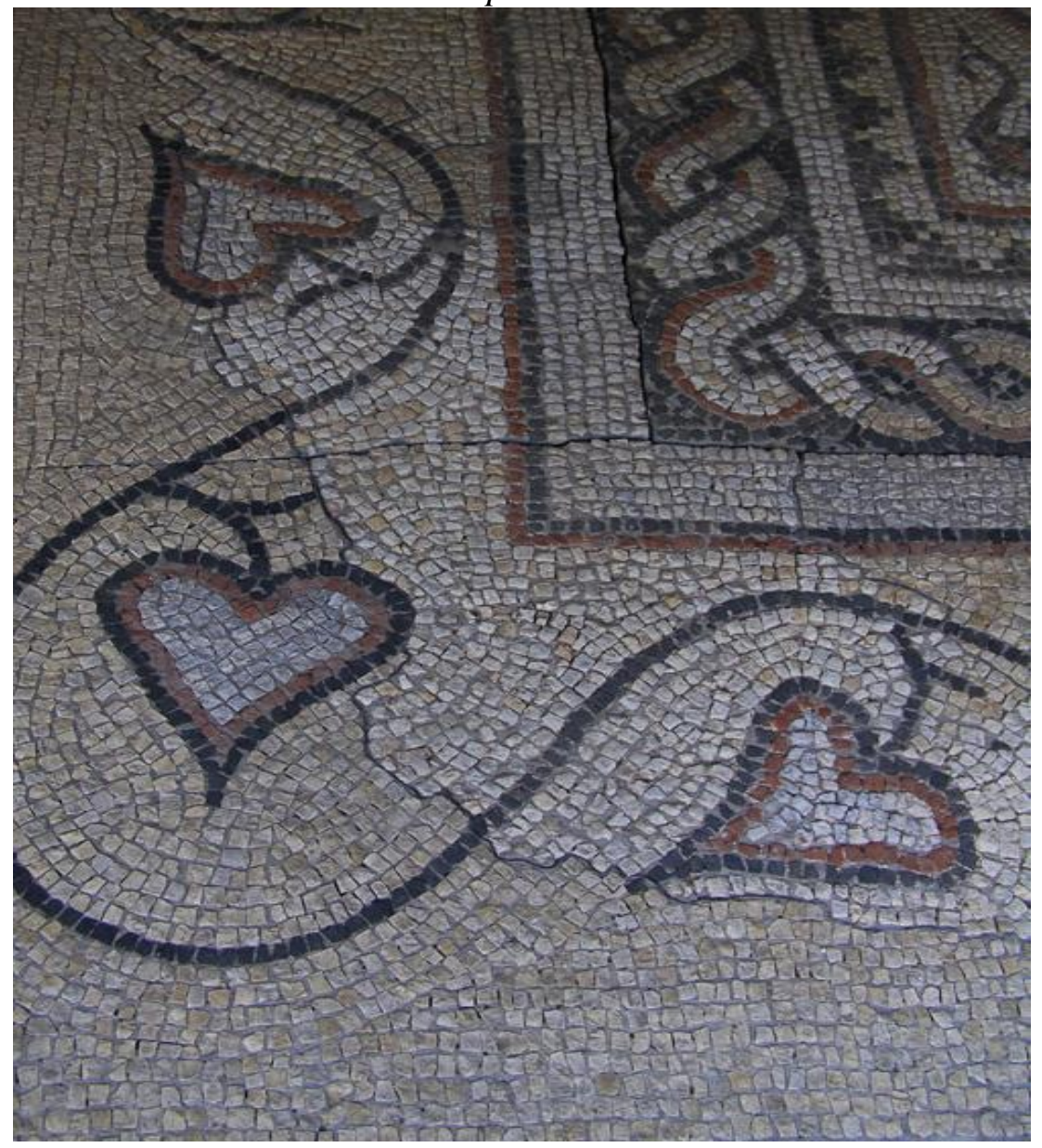

(Photo by M.V.Fomin) 
Figure 14. Museum of Mosaic in Apamea (Hama). A Bowl in a Triangle

(Photo by O.G. Checal)

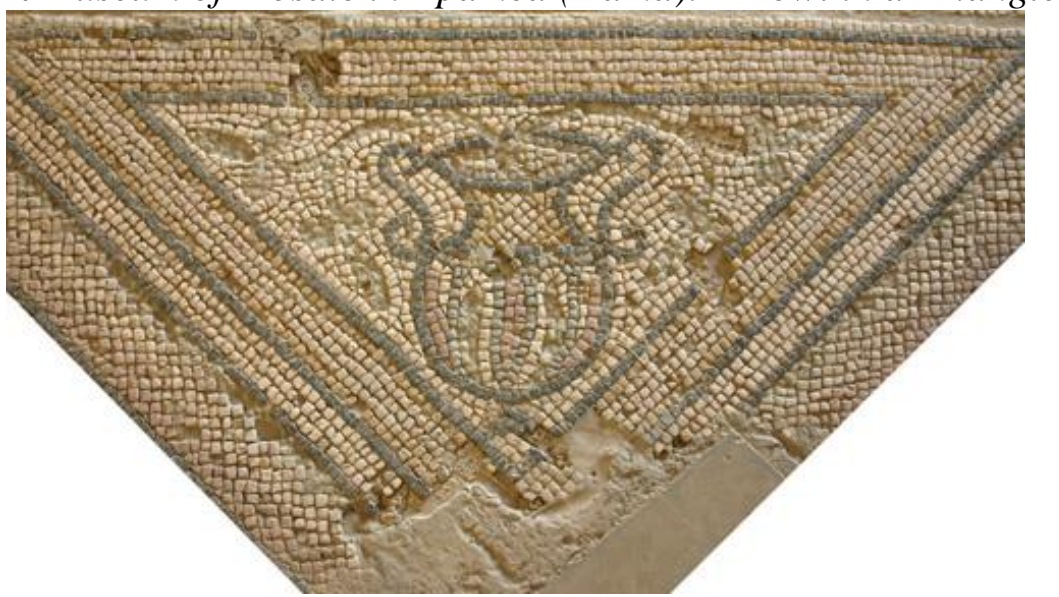

Figure 15. Museum of Mosaic in Apamea (Hama). A Bowl in a Triangle

(Photo by O.G. Checal)

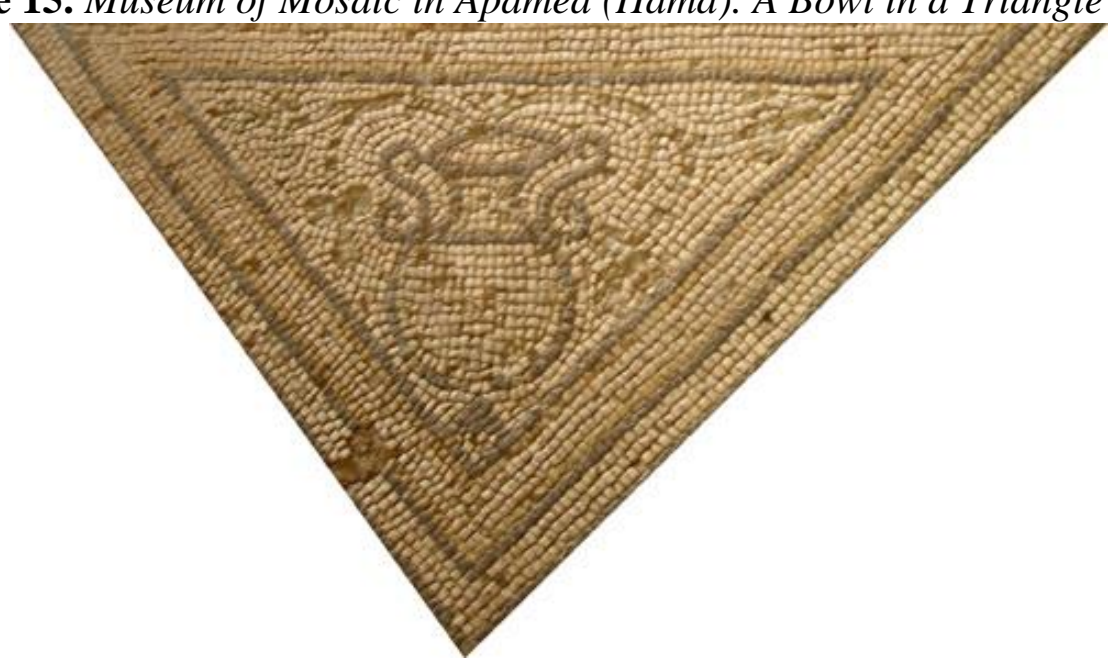

Compositions with the depictions of birds and a Vessel are of particular interest. The earliest depictions of peacocks are known from the wall-painted crypts of Chersonesos (mid 4th - 5th centuries (see Figure .8)). Such mosaics covered the floors of the Countryside Cruciform Church situated on the necropol (see Figure 5). Mosaics of similar composition were discovered in Syrian churches (see Figures 6, 7). Moreover, we can speak about a relatively early date for the creation of mosaics with the depiction of crosses, which were also included in the composition (see Figures 16,6). 
Figure 16. Chersonesos. A Cross.

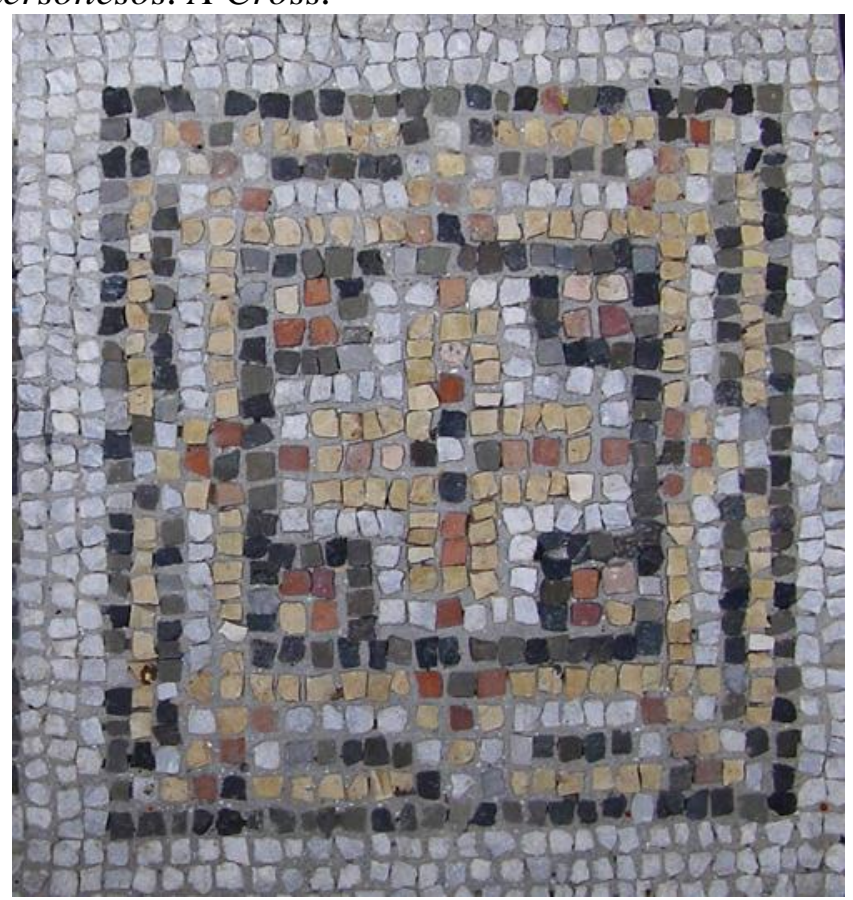

(Photo by M.V.Fomin)

Figure 17. Museum of Mosaic in Marra (Maraat an-numan). Crosses

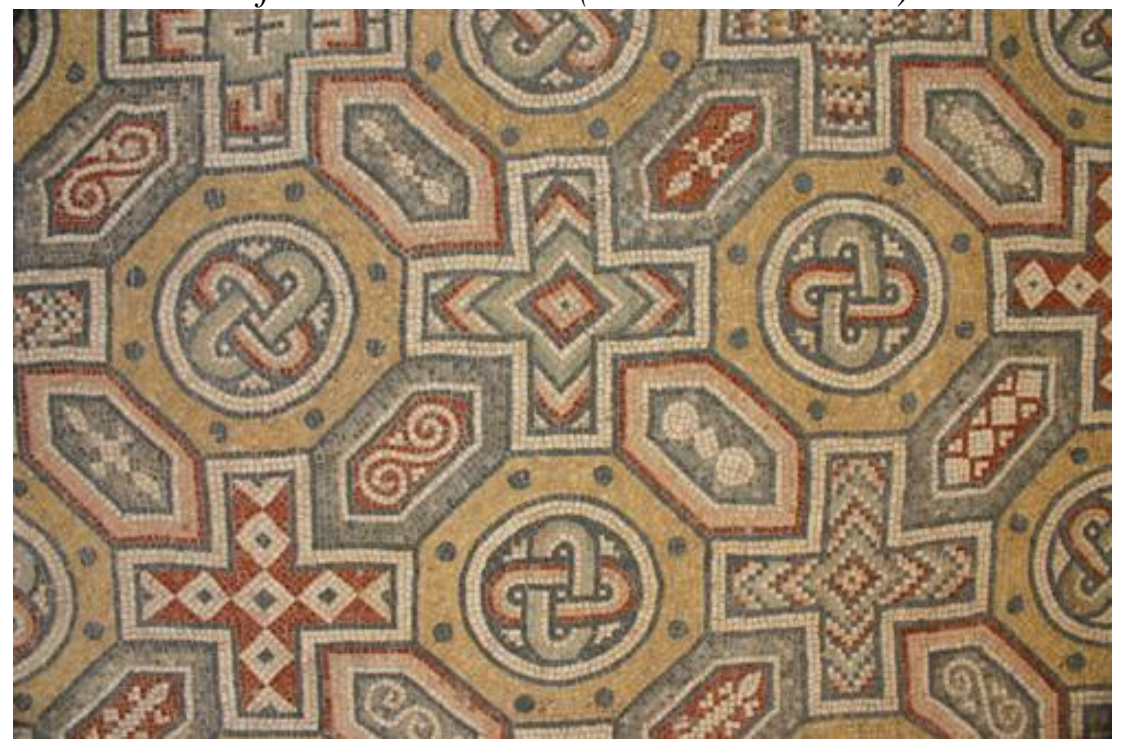

(Photo by O.G. Checal)

To sum up, one can state with certainty that close contacts between the eastern provinces of the Empire and Chersonesos-Kherson made a substantial impact on many aspects of the city's life, together with the spread of Christianity from the East. These artistic traditions were reflected in fresco paintings of the early Christian crypts of Chersonesos and in the mosaic floors of later churches. The existence of the artistic tradition was definitely reflected in the compositions of the floor mosaics of Chersonesos and Syria churches. In 
spite of some differences in depiction of individual elements, the design, in general, is similar. All this allows us to maintain that the system of floor mosaics paintings in Syria and Chersonesos has a common source. And, what is more, it would be logical to suggest that most of the artists belong to the Syrian artistic tradition for the origin of the artistic tradition in monumental paintings of Chersonesos.

\section{Bibliography}

Aynalov, D.V. "Razvaliny hramov" [Temple ruins], Monuments of Christian Chersonesos, vol. 1, (1905): 3-155.

Bert'e-Delagard, A.L "Drevnosti Juzhnoj Rossii. Raskopki Hersonesa" [Antiquities South Russia. Excavations Chersonesos] Materials for the archaeology of Russia. V. 12. St. Petersburg, (1893): 34-46.

Biederman, G. Enciklopedija simvolov. [Encyclopedia symbols]. Translated by I.S. Sventsitskaya Moscow, 1996.

Bolotov, V.V. Lekcii po istorii Drevnej Cerkvi. [Lectures on the History of the Ancient Church.] Kharkiv, 2007.

Bouras Ch. "City and Village: Urban and Architecture" Jahrbuch der Osterreichischen Byzantinistik 31, no. 2. (1981): 616 - 627.

Breasted, J. H. Oriental Forerunners of Byzantine Painting. Chicago, 1924

Chekal, A.G. Epigrafika v sakral'nom i pogrebal'nom iskusstve Pal'miry i DuraEvropos. [Epigraphy in the sacred and funerary art of Palmyra and DuraEuropos] Shodoznavchi studiï. News of Harkovskoï derzhavnoï akademiï design i Mistetstvo 9, no. 1, ed. V.Y. Danilenko (Kharkiv, 2008): 56-68.

Dombrovskij, O.I. Vizantijskie mozaiki Hersonesa Tavricheskogo [Byzantine mosaics Chersonesos.] Poznan, 2004.

Dvorkin, A. Ocherki po istorii Vselenskoj Pravoslavnoj Cerkvi. [Essays on the history of the universal Church.] Nizhny Novgorod, 2005.

Filippov, A.E. "Rospisi rannehristianskih sklepov Hersonesa Tavricheskogo v kontekste hudozhestvennoj tradicii: sintez s arhitekturoj, simvolika, liturgicheskaja osnova." [Early Christian painting crypts Chersonesos in the context of artistic tradition: the synthesis of architecture, symbolism, liturgical foundation], Essays on the History of the Christian Chersonesos, vol.1, issue. 1. (St Petersburg, 2009): 193-322.

Foss, C. "Archeology and the "Twenty Cities" of Byzantine Asia" American Journal of Archeology, vol. 81. (1977): 469 - 486.

Hadjar, Abdallah. The Church of St. Simeon the Stylite and other archaeological sites in the mountains of Simeon and Halaqa, S.L, 1995

Jacobson, A.L. "Rannesrednevekovyj Hersones: ocherki istorii material'noj kul'tury." [Early Medieval Hersonissos : Essays on the History of Material Culture], Materials and research on the archeology of the USSR, vol. 63 (MoscowLeningrad, 1959): 5-363.

Jacobson, A.L. "Srednevekovyj Hersones (XII-XIV vv.)" [Medieval Chersonesos (XII-XIV centuries)], Materials and research on the archeology of the USSR, vol. 17. (Moscow-Leningrad, 1950): 67-89.

Kadeev V.I. Hersones Tavricheskij. Byt i kul'tura (I-III vv. n. e.). [Chersonesos. Life and culture (I - III centuries. A.D.).] Kharkiv, 1996.

Kadeev, V.I., Sorochan, S.B. Ekonomicheskie svjazi antichnyh gorodov Severnogo 
Prichernomor'ja v I v. do n.e. $-V$ v. n.e. (po materialam Hersonesa).[Economic ties of ancient cities in the Northern Black Sea in the I. B.C. - V in. A.D. (based on the Chersonesos)]. Kharkiv, 1989.

Leiter, M. Iz materialov po izucheniju mozaichnyh polov Hersonesa Tavricheskogo. [From the materials for the study of the mosaic floors of Chersonesos]. Kharkiv, 1928.

Mogarichev, Ju.M., Sazanov, A.V., Sargsjan, T.Je., Sorochan, S.B., Shaposhnikov, A.K. "Zhitija episkopov Hersonskih v kontekste istorii Hersonesa Tavricheskogo" [Lives of the Bishops of Kherson in the context of the history of Chersonesos] Narteks. Byzantina Ukrainensis, vol.1. (Kharkiv: Antikva, 2012): 3-416.

Posnov, M. E. Istorija hristianskoj Cerkvi (do razdelenija cerkvej - 1054). [History of the Christian Church (before the separation of church - 1054).] Brussels, 1964.

Romanchuk, A.I. Issledovanija Hersonesa - Hersona. [Research Chersonesos Kherson]. Part 2. Ekaterinburg, 2007.

Rostovtzeff, M. I. Dura - Europos and its Art. Oxford, 1938.

Rostovtzeff, M. I. Antichnaya dekorativnaya zhivopis' na yuge Rossii [Ancient Decorative Painting in South Russia] Saint Petersburg, 1914.

Sorochan, S.B., Zubar, V.M., Marchenko, L.V. Zhizn' i gibel' Hersonesa. [Life and death of Chersonesos.] Kharkov, 2000.

Strzheletskiy, S.F. "Antichnye pamjatniki Hersonesa iz raskopok 1950 g."[Chersonesos ancient monuments from the excavations in 1950], Journal of Ancient History, no. 2. (1951): 136-141.

Strzygowski, J. Orient oder Rom: Beitrige zur Geschichte der Spitantiken und Frihchristlichen Kunst. Leipzig, 1901.

Uvarov, A. Hristianskaja simvolika. [Christian symbolism]. Moscow, 1908

Weitzmann, K. The Frescoes of the Dura Synagogue and Christian Art. Washington: Dumbarton Oaks, 1990.

Weizmann, K. Late Antique and Early Christian Book Illumination. New-York, 1977.

Xoll, J. Slovar' sjuzhetov $i$ simvolov v iskusstve. [Dictionary of subjects and symbols in art.], Translated by A. Maikapara. Moscow, 1996. 
